\title{
Analisis Struktur Bangunan Rumah Tinggal di Desa Jumoyo yang Berisiko Terhadap Banjir Lahar Dingin Gunung Merapi
}

\author{
Taufiq Ilham Maulana* ${ }^{a *}$ Sofyan Sahuri Syarif ${ }^{a}$ \\ ${ }^{a}$ Program Studi Teknik Sipil, Fakultas Teknik, Universitas Muhammadiyah Yogyakarta \\ ${ }^{b}$ Dinas Pekerjaan Umum dan Perumahan Kabupaten Sleman
}

Riwayat Artikel

Diserahkan

1 Desember 2020

Direvisi

4 Januari 2021

Diterima

1 Februari 2021

${ }^{*}$ Penulis korespondensi

taufiq.im@umy.ac.id

\begin{abstract}
Abstrak
Desa Jumoyo merupakan daerah rawan bencana yang salah satunya disebabkan oleh banjir lahar dingin. Banjir lahar dingin dari erupsi Gunung Merapi telah menyebabkan kerusakan bangunan pada pemukiman penduduk, infrastruktur, dan lahan pertanian. Hal ini juga mengakibatkan peningkatan risiko pada keselamatan nyawa manusia yang tinggal di bangunan. Oleh karena itu, bangunan rumah harus mampu memberikan rasa aman bagi penghuninya. Penelitian ini membahas tentang analisis ketahanan bangunan rumah tinggal terhadap banjir lahar dingin yang disusun dalam dua tahapan. Tahap pertama, bangunan rumah tinggal dan penghuninya dianalisia dengan berdasarkan elevasi dari garis kontur dengan menggunakan software QGIS yang bersifat open source dan user friendly. Bangunan yang dianalisa berupa bangunan rumah tinggal satu lantai dan dua lantai. Berdasarkan hasil survei, penghuni bangunan 1 lantai diasumsikan sebanyak 4 orang untuk bangunan $<72 \mathrm{~m}^{2}, 8$ orang untuk bangunan $\geq 72 \mathrm{~m}^{2}$, dan 6 orang untuk bangunan 2 lantai. Tahap kedua, analisis kegagalan elemen struktur bangunan terhadap tekanan banjir lahar dingin dilakukan menggunakan SAP2000. Jumlah bangunan yang berisiko sebanyak 103 dan jumlah penghuni bangunan diperkirakan sebanyak 664 orang. Jumlah kegagalan elemen struktur bangunan rumah tinggal satu lantai dan dua lantai yang ditentukan oleh ukuran kolom dan balok, serta tinggi tekanan banjir lahar dingin.
\end{abstract}

Kata-kata bangunan rumah tinggal, banjir lahar dingin, Desa Jumoyo, kegagalan struktur

(C) 2021 Penerbit UMY. All rights reserved

\section{PENDAHULUAN}

Secara geografis, Kabupaten Magelang merupakan daerah rawan bencana yang salah satunya disebabkan oleh banjir lahar dingin. Banjir lahar dingin dari erupsi Gunung Merapi pada tahun 2010 telah menyebabkan kerusakan bangunan pada permukiman penduduk, infrastruktur, dan lahan pertanian. Keruntuhan bangunan rumah tinggal yang diakibatkan oleh bencana banjir lahar dingin cukup besar. Kumalawati dkk (2013) melakukan evaluasi terhadap pengembangan wilayah permukiman berdasarkan pemetaan kerusakan akibat banjir lahar di Kali Putih. Metode yang digunakan adalah GPS Tracking untuk mengetahui luapan banjir lahar dan klasifikasi tingkat kerusakan permukiman berdasar kriteria yang telah ditetapkan. Kumalawati (2015) melanjutkan penelitiannya tentang valuasi ekonomi tingkat kerusakan bangunan permukiman akibat banjir lahar di Kali Putih. Kajiannya meliputi survei fisik luapan aliran di kali Putih dan administratif zonasi yang berdasarkan pada tiap kecamatan dengan mengambilan sampel yang diwakili oleh responden dengan melakukan Focus Group Discussion (FGD).

Li dkk. (2017) melakukan penelitian tentang respons dinamik struktur batu bata yang dipengaruhi oleh aliran debris. Hasil penelitian menunjukkan bahwa kawat yang dipasang menyilang mampu menghentikan batuan dalam aliran debris dan menghilangkan energi yang membuat deformasi. Li dkk (2018) melanjutkan penelitiannya tentang studi parametrik pada respon dinamis dari Struktur batu bata dengan Fiber Reinforced Polymer (FRP) di bawah dampak aliran debris. Tujuan dari penelitian ini adalah untuk menyelidiki pengaruh parameter yang berbeda dengan kinerja FRP pada struktur batu bata di bawah aliran debris menggunakan model elemen hingga dengan menggunakan perangkat lunak LSDYNA. Zeng. dkk (2014) memperkirakan kecepatan kritis aliran debris ketika kolom terkena aliran debris dan partikelnya menggunakan teori material dan mekanik 
struktural. Hasil penelitian menunjukkan bahwa jenis aliran debris, ukuran partikel dalam aliran, dan lokasi mempengaruhi kondisi kritis. Pratama dan Elvira (2013) melakukan pemodelan 3D rumah tinggal dua lantai (bangunan eksisting) dengan metode elemen hingga. denganbeban yang direncanakan adalah beban gravitasi dan beban lateral (gempa). Hasil simulasi menunjukkan bahwa terjadi kegagalan pada beberapa daerah balok, dinding, dan lantai, dengan indikasi dari besarnya tegangan yang terjadi telah melebihi batasan kuat tekan beton.

Oleh karena itu, bangunan rumah tinggal harus direncanakan untuk dapat memberikan rasa aman. Penelitian ini membahas tentang analisis ketahanan bangunan rumah tinggal terhadap banjir lahar dingin. Penelitian ini menganalisis persebaran bangunan rumah tinggal di Desa Jumoyo yang berisiko terhadap banjir lahar dingin. Penelitian ini juga menganalisis kegagalan elemen struktur bangunan rumah tinggal terhadap tekanan banjir lahar dingin.

\section{METODE PENELITIAN}

Penelitian ini disusun dalam dua tahapan utama. Tahap pertama, bangunan rumah tingal di Desa Jumoyo dianalisis situasi dan kondisinya berdasarkan peta satelit Google Earth dan peta Rupa Bumi Indonesia. Analisis ini diproses dalam program komputer yang berbasis Geographic Information System (GIS), dengan menggunakan software. Quantum GIS. Quantum GIS (QGIS) merupakan software digitasi untuk data spasial keruangan yang bersifat open source dan user friendly. Tahap kedua, bangunan rumah tinggal yang berisiko dianalisis kegagalan strukturnya terhadap tekanan banjir lahar dingin dengan menggunakan software SAP2000 versi 21.

\subsection{Pengumpulan Data}

Penelitian ini menggunakan dua model bangunan rumah tinggal yaitu bangunan satu lantai dan dua lantai. Bangunan rumah tinggal satu lantai berukuran $6 \mathrm{~m} \times 12$ $\mathrm{m}$ dengan jarak antar kolom selebar $3 \mathrm{~m}$ dan tinggi kolom $3 \mathrm{~m}$. Bangunan rumah tinggal dua lantai berukuran $6 \mathrm{mx}$ $9 \mathrm{~m}$ dengan jarak antar kolom selebar 3 meter dan tinggi antar kolom $3 \mathrm{~m}$. Bangunan rumah tinggal satu lantai dan dua lantai memiliki ukuran kolom dan balok yang sama. Kolom dan balok bangunan rumah tinggal diasumsikan dalam empat ukuran yang disajikan dalam Tabel 1 . Gambar 1 menampilkan sketsa model bangunan rumah yang dikaji dalam penelitin ini.

Tulangan yang digunakan berdasarkan SNI 2052 2014 (BSN. 2014) yaitu BjTP 24 yang memiliki tegangan leleh minimum $\left(f_{\mathrm{y}}\right)$ sebesar $235 \mathrm{MPa}$ dan tegangan putus minimum $\left(f_{\mathrm{u}}\right)$ sebesar $380 \mathrm{MPa}$, sedangkan mutu beton $\left(f^{\prime}{ }_{c}\right)$ yang digunakan sebesar $20 \mathrm{MPa}$. Bangunan rumah tinggal satu lantai menggunakan tulangan utama D12 mm dan sengkang D10 mm, sedangkan bangunan dua lantai menggunakan tulangan utama D16 mm dan sengkang D10 mm.

Dinding bangunan rumah tinggal menggunakan pasangan jenis bata beton (batako) yang memiliki tebal 15
Tabel 1 Data ukuran kolom dan balok

\begin{tabular}{cc}
\hline Dimensi Kolom & Dimensi Balok \\
\hline $20 \times 20 \mathrm{~cm}$ & $15 \times 20 \mathrm{~cm}$ \\
$25 \times 25 \mathrm{~cm}$ & $20 \times 25 \mathrm{~cm}$ \\
$30 \times 30 \mathrm{~cm}$ & $25 \times 30 \mathrm{~cm}$ \\
$35 \times 35 \mathrm{~cm}$ & $30 \times 35 \mathrm{~cm}$ \\
\hline
\end{tabular}

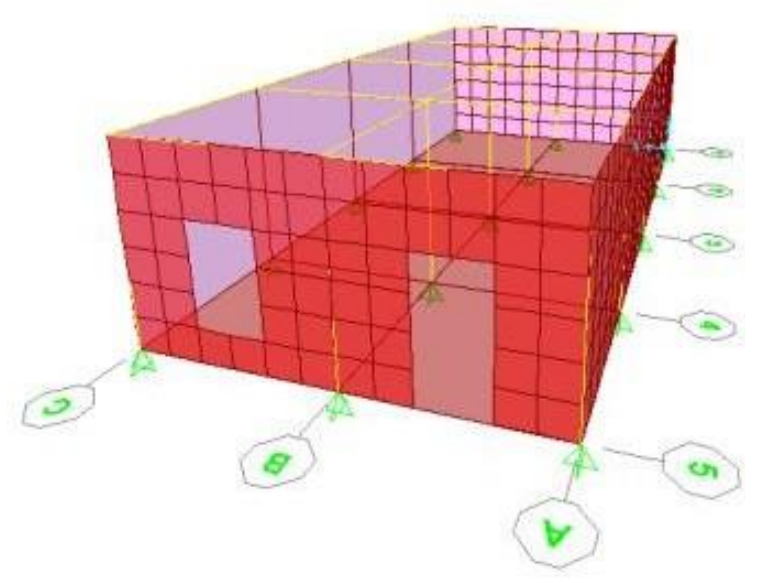

(a)

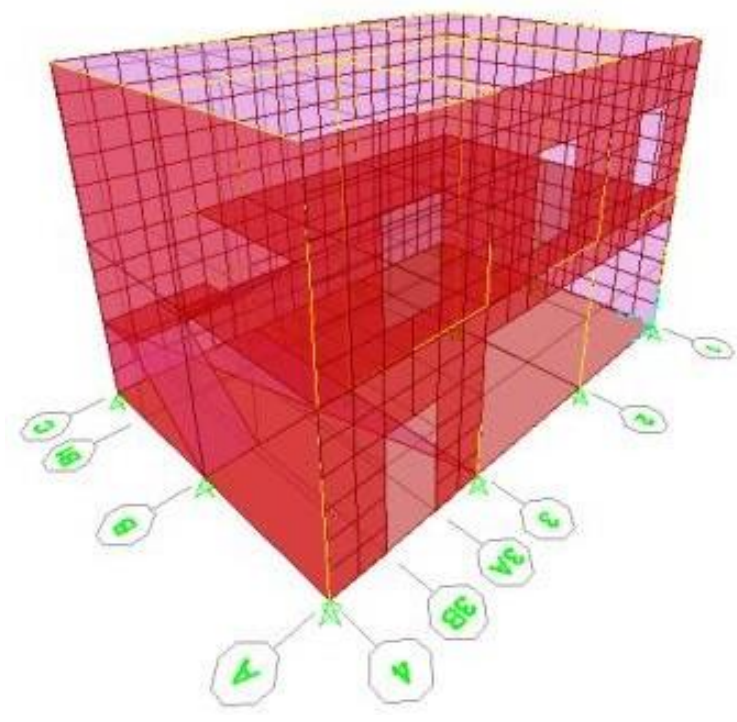

(b)

Gambar 1 Bangunan rumah tinggal satu lantai, (b) dua lantai

cm. Bata beton ini sesuai SNI 03-0349-1989 (BSN, 1989) yang merupakan bata beton kelas III dan memiliki kuat tekan $\left(f_{c}{ }^{\prime}\right) 40 \mathrm{~kg} / \mathrm{cm}^{2}$ atau setara dengan 3,9 MPa. Dinding bangunan diasumsikan menyatu dengan balok dan kolom, sehingga analisis dilakukan hanya pada struktur balok dan kolom.

\subsection{Pembebanan}

Beban adalah gaya luar yang bekerja pada suatu struktur bangunan. Beban yang diaplikasikan pada model bangunan rumah tinggal berdasarkan SNI 1727-2013 BSN, 2013). Akibat dorongan material lahar dingin pada struktur bangunan maka akan mendapat tekanan berupa tekanan lateral. Beban lahar dingin diasumsikan sama dengan tekanan pada zat cair dan zat padat, karena material lahar dingin didominasi oleh campuran air dan pasir. Beban lahar dingin ini diasumsikan sebagai beban statis, sehingga kecepatan aliran banjir lahar dingin diabaikan. Beban lahar dingin sesuai dengan bobot isi pasir rerata musim penghujan yang berada di Kali Putih 


\begin{tabular}{cc} 
Tabel 2 Ketinggian banjir lahar dingin \\
\hline Tahap & Ketinggian $(\mathrm{m})$ \\
\hline 1 & 0,5 \\
2 & 1,0 \\
3 & 1,5 \\
4 & 2,0 \\
5 & 2,5 \\
6 & 3,0 \\
\hline
\end{tabular}

Tabel 3 Jumlah bangunan rumah tinggal dan penghuni yang berisiko

\begin{tabular}{|c|c|c|c|}
\hline \multirow{3}{*}{$\begin{array}{l}\text { Ketinggian Banjir Lahar } \\
\text { Dingin }\end{array}$} & \multicolumn{3}{|c|}{ Jumlah bangunan rumah tinggal } \\
\hline & \multicolumn{2}{|c|}{ Satu lantai } & \multirow[t]{2}{*}{ Dua Lantai } \\
\hline & Luas bangunan $<72 \mathrm{~m}^{2}$ & Luas bangunan $\geq 72 \mathrm{~m}^{2}$ & \\
\hline $3 \mathrm{~m}$ & 13 & 8 & 0 \\
\hline $6 \mathrm{~m}$ & 68 & 33 & 2 \\
\hline & \multicolumn{3}{|c|}{ Jumlah penghuni di rumah tinggal } \\
\hline $\begin{array}{l}3 \mathrm{~m} \\
6 \mathrm{~m}\end{array}$ & $\begin{array}{r}52 \text { orang } \\
272 \text { orang }\end{array}$ & $\begin{array}{r}64 \text { orang } \\
264 \text { orang }\end{array}$ & $\begin{array}{l}0 \\
12 \text { orang } \\
\end{array}$ \\
\hline
\end{tabular}

sebesar 1934 kg/m³ (Endroyo, 2007). Ketinggian tekanan banjir lahar dingin diasumsikan dalam 6 tahap ketinggian seperti pada Tabel 2 .

Kombinasi pembebanan merupakan kombinasi dari beberapa beban yang dapat bekerja secara bersamaan. Kombinasi pembebanan ini disebabkan oleh bekerjanya beban mati, beban hidup, dan beban lahar dingin. Nilainilai tersebut dikalikan dengan suatu faktor yang disebut faktor beban, tujuannya agar struktur dan komponennya memenuhi syarat kekuatan dan layak pakai terhadap berbagai kombinasi beban. Beban bangunan rumah tinggal dalam penelitian ini didefinisikan sebagai beban mati (D), beban hidup (L), dan beban lahar dingin (S). Komponen pembebanan pada struktur dapat dikombinasikan menjadi (a) 1,4D; (b) 1,2D + 1,6S; dan (c) $1 \mathrm{D}+1 \mathrm{~L}+1 \mathrm{~S}$

\section{HASIL DAN PEMBAHASAN}

\subsection{Risiko Bangunan Rumah Tinggal Terhadap Banjir} Lahar Dingin

Berdasarkan model peta elevasi dari garis kontur Desa Jumoyo dapat diketahui banyaknya bangunan rumah tinggal yang berisiko terkena banjir lahar dingin seperti disajikan pada Gambar 2. Banjir lahar dingin berdasarkan elevasi garis kontur dalam peta yang telah dibuat menggunakan program QGIS terdapat dua tahap ketinggian banjir lahar dingin. Tahapan tersebut yaitu banjir dengan ketinggian $3 \mathrm{~m}$ dan $6 \mathrm{~m}$. Bangunan rumah tinggal yang berisiko terdampak banjir lahar dingin diilustrasikan dalam Gambar 3. Berdasarkan Gambar 3, kedalaman Kali Putih yaitu $5 \mathrm{~m}$. Kali Putih saat terjadi banjir dengan ketinggian 3 meter, aliran banjir dapat mencapai bangunana yang paling dekat dengan sungai. Saat banjir mencapai ketinggian tersebut, maka bangunan

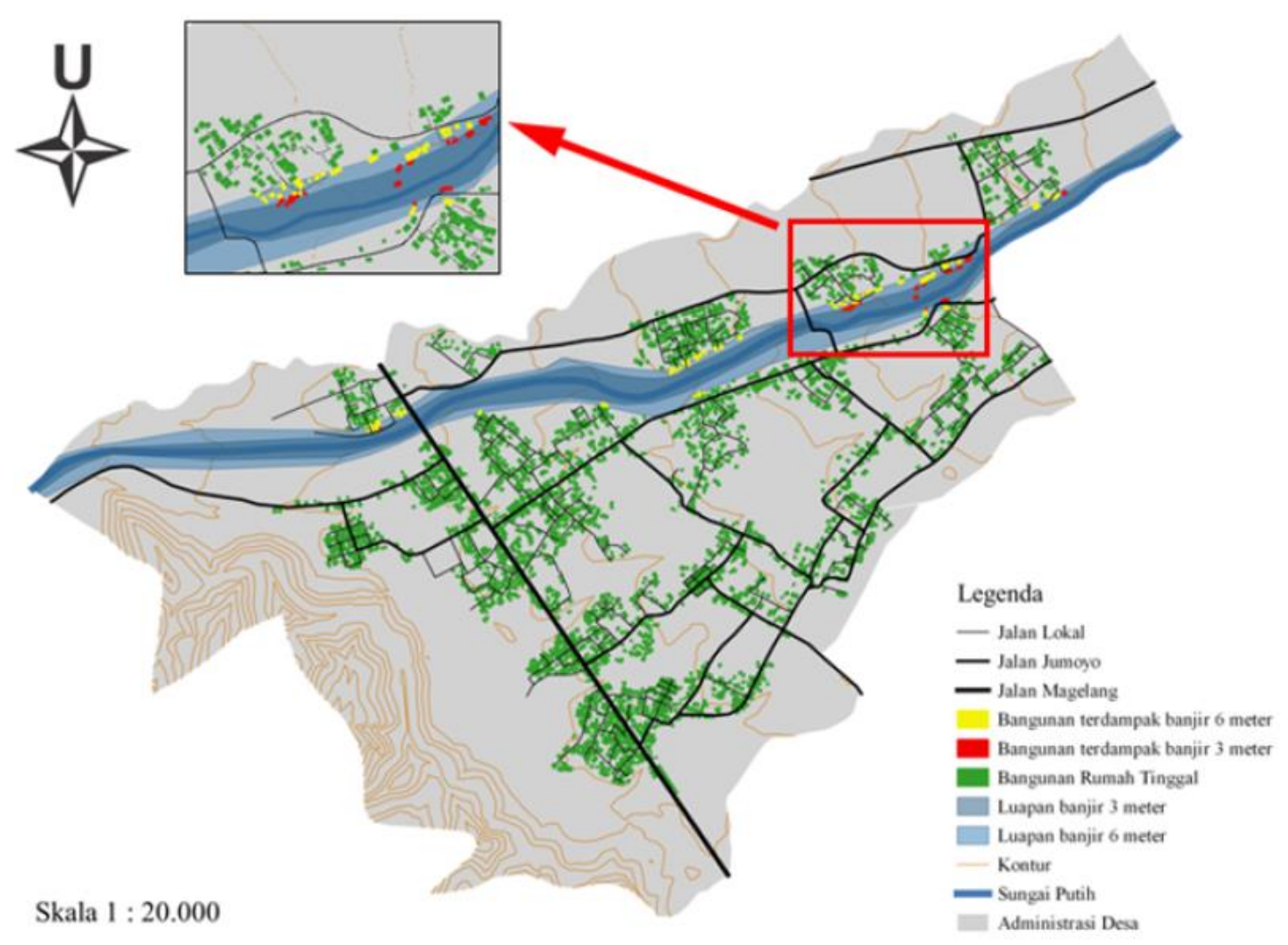

Gambar 2 Peta bangunan rumah tinggal yang berisiko terdampak banjir lahar dingin 
yang paling bawah terkena aliran banjir lahar dingin. Pada saat ketinggian banjir 6 meter, lahar dingin dapat mencapai bangunan diatasnya. Distribusi tekanan lateral akibat lahir dingin disajikan pada Gambar 4.

Berdasarkan hasil survei, jumlah orang yang tinggal dalam satu bangunan rumah tinggal satu lantai dibedakan berdasarkan jumlah keluarga yang tinggal di bangunan dan berdasarkan luas bangunan tersebut. Bangunan rumah tinggal satu lantai yang dihuni oleh satu keluarga dengan jumlah penghuni empat orang memiliki luas bangunan $<72 \mathrm{~m}^{2}$, sedangkan bagunan rumah tinggal 1 lantai yang dihuni oleh dua keluarga dengan jumlah penghuni 8 orang memiliki luas bangunan $\geq 72 \mathrm{~m}^{2}$. Bangunan rumah tinggal dua lantai tidak dibedakan berdasarkan jumlah keluarga ataupun luas bangunan. Bangunan rumah tinggal dua lantai dihuni oleh satu keluarga yang terdiri dari 6 orang. Jumlah bangunan rumah tinggal yang berisiko dan jumlah penghuni bangunan yang berisiko disajikan dalam Tabel 3 . Bangunan rumah tinggal yang berisiko terdampak banjir lahar dingin dengan ketinggian 3 meter sebanyak 21

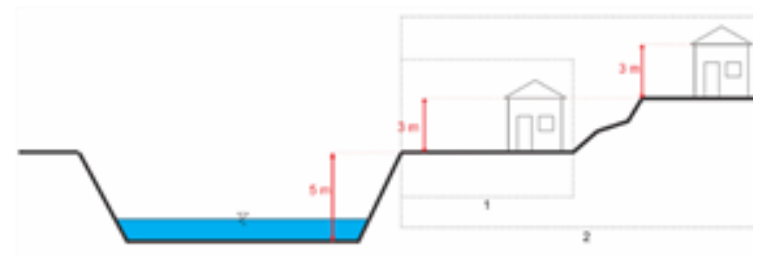

Gambar 3 Risiko bangunan di bantaran sungai

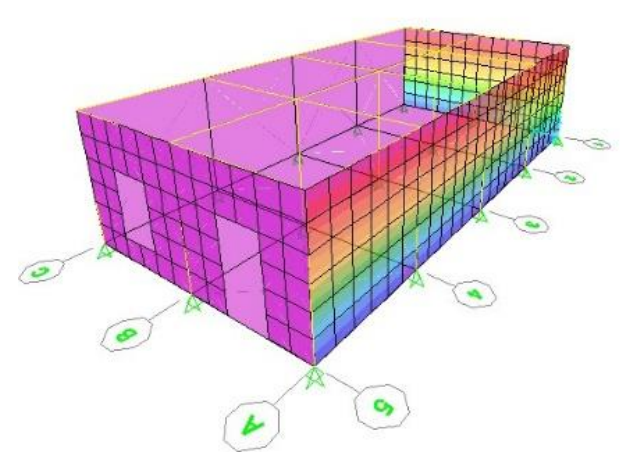

(a)

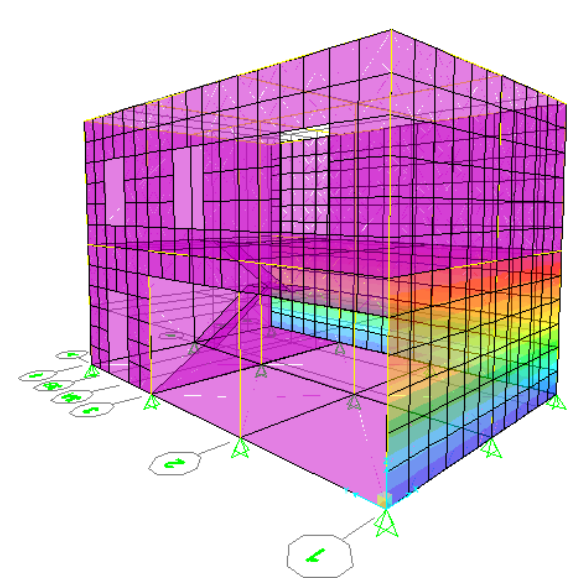

(b)

Gambar 4 Tekanan banjir lahar dingin $3 \mathrm{~m}$ pada bangunan rumah tinggal (a) 1 lantai, (b) 2 lantai. rumah, sedangkan yang terdampak banjir dengan ketinggian 6 meter sebanyak 103 rumah. Jumlah penghuni bangunan rumah tinggal yang berisiko terdampak banjir lahar dingin pada ketinggian 3 meter diperkirakan sebanyak 116 orang, sedangkan dampak banjir dengan ketinggian 6 meter diperkirakan sebanyak 664 orang.

\subsection{Analisis Struktur Bangunan Rumah Tinggal}

Hasil dari analisis struktur bangunan rumah tinggal menggunakan program SAP2000 versi 21 menunjukkan jumlah kegagalan elemen struktur. Kegagalan struktur pada bangunan rumah tinggal satu lantai dan dua lantai diakibatkan karena rasio kapasitas melebihi batas maksimum yang diizinkan. Bangunan rumah tinggal satu lantai dalam penelitian ini berukuran 12 × $6 \mathrm{~m}$. Luas bangunan rumah tinggal tersebut yaitu $72 \mathrm{~m}^{2}$. Jumlah total elemen pada struktur bangunan ini sebanyak 37 . Jumlah kegagalan struktur bangunan rumah tinggal satu lantai dari hasil analisis menggunakan program SAP2000 ditampilkan dalam grafik pada Gambar 5. Bangunan rumah tinggal dua lantai dalam penelitian ini berukuran $9 \times 6 \mathrm{~m}$. Bangunan rumah tinggal tersebut memiliki luas $54 \mathrm{~m}^{2}$. Jumlah total elemen pada struktur bangunan ini sebanyak 59. Berdasarkan analisis program SAP2000, jumlah kegagalan struktur bangunan rumah tinggal dua lantai ditampilkan dalam grafik pada Gambar 6 .

Gambar 5 dan 6 menunjukkan jumlah kegagalan elemen struktur berdasarkan empat ukuran balok dan kolom. Ukuran balok dan kolom serta ketinggian lahar dingin berpengaruh terhadap banyaknya kegagalan elemen struktur Hal ini menujukkan jika ukuran balok dan kolom diperbesar maka semakin sedikit jumlah kegagalan strukturnya. Grafik tersebut juga menunjukan jika banjir lahar dingin semakin tinggi maka jumlah kegagalan elemen strukturnya semakin bertambah. Solusi untuk mengatasi kegagalan elemen struktur yaitu memperkuat dinding bangunan rumah tinggal dengan menambahkan penyangga kawat. Penyangga kawat tersebut dipasang menyilang pada dinding antar kolom untuk meningkatkan ketahanan struktur batako. Solusi lainya yaitu meningkatkan kualitas material penyusun

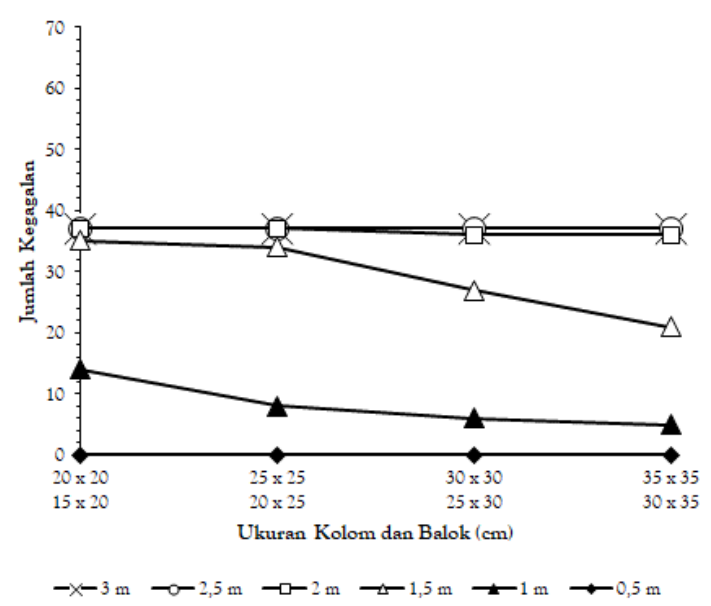

Gambar 5 Jumlah kegagalan struktur bangunan rumah tinggal satu lantai 


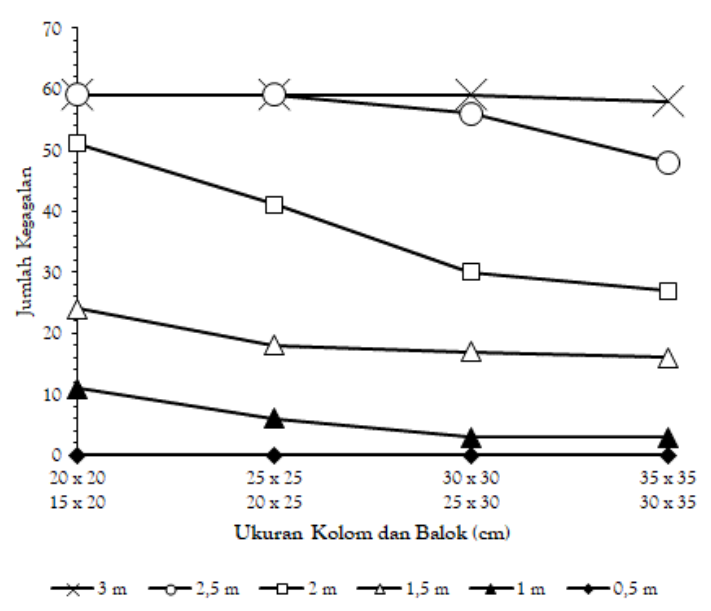

Gambar 6 Jumlah kegagalan struktur bangunan rumah tinggal dua lantai

dinding yaitu dengan mengganti bata beton (batako) menjadi beton ringan.

\section{KESIMPULAN}

Berdasarkan hasil analisis yang telah dilakukan, diketahui bahwa bangunan rumah tinggal yang beresiko terdampak banjir lahar dingin setinggi $3 \mathrm{~m}$ sebanyak 21 rumah dengan jumlah penghuni sebanyak 116 orang. Bangunan rumah tinggal yang beresiko terdampak banjir lahar dingin setinggi $6 \mathrm{~m}$ sebanyak 103 rumah dengan jumlah penghuni sebanyak 664 orang.

Selain itu, jumlah kegagalan struktur pada bangunan rumah tinggal 1 lantai ataupun 2 lantai tergantung ukuran eksisting balok dan kolom serta ketinggian banjir lahar dingin. Dengan dimensi penampang struktur yang besar dan ketinggian banjir yang rendah maka jumlah kegagalan struktur semakin berkurang. Kegagalan struktur paling sedikit yaitu pada simulasi ketinggian banjir lahar dingin 0,5 meter, dan paling banyak pada simulasi ketinggian banjir lahar dingin 3 meter.

Penelitian ini bersumber dari data sekunder dan berbagai asumsi telah dipertimbangkan, sehingga hasil kesimpulan yang diambila hanya sesuai apabila kondisi nyata mendekati dengan asumsi. Penelitian ini dapat bermanfaat sebagai peringatan dini bagi masyarakat yang tinggal di bantaran Kali Putih dan pemerintah daerah yang berwenang serta meningkatkan tingkat kesadaran akan bahaya banjir lahar dingin terhadap bangunan rumah tinggal.

\section{Daftar Pustaka}

BSN. 2014. SNI 2052:2014: Baja Tulangan Beton. Badan Standardisasi Nasional. Jakarta.

BSN. 1989. SNI 03-0349-1989: Bata Beton Untuk Pasangan Dinding. Badan Standardisasi Nasional. Jakarta.

BSN. 2013. SNI 1727-2013: Beban Minimum Untuk Perancangan Gedung Dan Struktur Lain. Badan Standardisasi Nasional. Jakarta.

Endroyo B., 2007. Kualitas Pasir Muntilan (Jawa Tengah) Ditinjau dari Tempat Pengambilan dan Musim Pengambilan. Wahana Teknik Sipil, 12. 1. 1-8.

Kumalawati, Rosalina. Rijal, Seftiawan Samsu. Rijanta. Sartohadi, Jujun. dan Pradiptyo, Rimawan. 2013. Evaluasi Pengembangan Wilayah Permukiman Berdasarkan Pemetaan Kerusakan Permukiman Akibat Banjir Lahar di Kali Putih, Kabupaten Magelang. Tataloka, 15.(1). 13-27.

Kumalawati R., Rijanta, R. Sartohadi, Junun. Pradiptyo, Rimawan. dan Rijal, Seftiawan Samsu. 2013. Valuasi Ekonomi Tingkat Kerusakan Bangunan Permukiman Akibat Banjir Lahar Di Kali Putih Kabupaten Magelang. Jurnal Bumi Lestari, 13(2). 341-354.

Kumalawati R. 2015. Pengelolaan Bencana Lahar Gunung Api Merapi. Yogyakarta: Penerbit Ombak.

Li, P., Li, T, Lu, Z.. dan Li, J., 2017. Study on Dynamic Response of Novel Masonry Structures Impacted by Debris Flow. Journal Sustainability. 9.(7). 1-22.

Li, P., Li T., Lu Z., dan Li J. 2018. Parametric Study on Dynamic Response of FRP Masonry Structures under the Impacts of Debris Flow. Hindawi Shock and Vibration, 10. 1155. 1-20.

Pranata, Y.A., dan Elvira L., 2013. Analisis Kegagalan Struktur Bangunan Rumah Tinggal Dengan Metode Elemen Hingga Linier. Jurnal Teknik Sipil, 12(3). 161-172.

Setiawan, A. 2016. Perancangan Struktur Beton Bertulang Berdasar SNI 287:2013. Jakarta: Penerbit Erlangga.

Undang-Undang Republik Indonesia Nomor 1 Tahun 2011 tentang Perumahan dan Kawasan Permukiman.

Widowati, A.P.A. 2017. Hydraulic and Hydrologic Modeling of Steep Channel of Putih River, Magelang District, Central Java Province Indonesia. Civil Engineering Forum, 3(3). 125-134.

Zeng C., Cui P., Su Z., Lei Y., dan Chen R., 2014. Failure Modes of Reinforced Concrete Columns of Buildings Under Debris Flow Impact. Landslides, 12(3). 561-571. 